\title{
QUALITY INDICATORS: CARCAS SIDE AND MEAT QUALITY OF PIGS OF DIFFERENT GENOTYPES
}

\author{
O. Kosovac, B. Živković, Č. Radović, T. Smiljaković \\ Institute for Animal Husbandry, Belgrade-Zemun, Zemun 11080, Serbia \\ Correpsonding author: okos@,sezampro.rs \\ Original scientific paper
}

Abstract: In the paper, lean meat and quality of meat from pigs of 5 different genotypes were investigated: pure Landrace breed (L), genotype A; two hybrid combinations (Large Yorkshire x Landrace) x Duroc (LY x L) x D, genotype B; (Large Yorkshire x Landrace) x Pietrain (LY x L) x P, genotype $\mathrm{C}$; and tow recurrent mating combinations: (Large Yorkshire $\mathrm{x}$ Landrace) x Large Yorkshire (F1 x LY, genotype D) and (Large Yorkshire $\mathrm{x}$ Landrace) $\mathrm{x}$ Landrace (F1 x L, genotype E). Relevant indicators of lean meat were analyzed early post mortem and by method of partial dissection on cooled left carcass sides according to recommendation of EU. By analysis of obtained results it was established that the best indicator of lean meat of pig carcass sides mass of muscle tissue in four main parts. This conclusion derives from the fact that fatteners (genotype $\mathrm{C}$ ) which had the greatest mass of muscle tissue in four main parts $(15,33 \mathrm{~kg})$ also had the highest lean meat share in leg, shoulder, back-loin part (BLP) and belly-rib part (BRP) $(69,67 \%, 57,71 \%, 54,42 \%$ and $44,99 \%)$ and highest share of muscle tissue in carcass sides when any of the mentioned investigation methods was applied $(51,23$ and $60,73 \%)$ compared to fatteners of other investigated genotypes. The quality of meat was investigated by determination of its technological quality and chemical composition of the MLD. Technological quality and chemical composition of MLD meat exhibited significant $(* p<0,05)$ differences in WBC and pigment content between genotypes B and C, as well as B and $\mathrm{E}$. Average values for content of ashes and share of pigments corresponds with average values characterizing muscles of normal properties. By analysis of obtained results we can conclude that fatteners of genotype $\mathrm{E}$ had the highest meat yield in carcass sides, but of slightly lower quality, which indicates the need for further work on improvement of meat quality.

Key words: quality indicators, quality of carcass/carcass sides and meat, evaluation methods, genotype 


\section{Introduction}

Lean meat, i.e. quality of pig carcasses, which is one of the measures present in the selection program, is expressed by percentage of meat, and for this purpose different selection schemes are applied with the same objective (Ducos, 1994, cit. po Le Roy, 2002).

Indicators of lean meat are indicators of quality of pig carcasses and include various types of measurements, on different locations and carried out in different ways. Most of the measurements represent fat content and are used as indirect evaluation of lean meat of pig carcasses. So, Hazel and Kline (1952, cit. po Moeller-u, 2001) for invasive method, measured back fat thickness on live and slaughtered animals. Authors have established high correlation of this measures on live and slaughtered animals $(\mathrm{r}=0,80)$. Using non-invasive methods on the same area Claus (1957, cit. po Moeller, 2001) and Hazel and Kline (1959, cit. po Moeller, 2001) achieved pioneer work using ultrasound. Namely, back fat thickness measured by ultrasound was in high correlation with back fat thickness on carcass, and total fat tissue in slaughtered carcass. By introduction of ultrasound measuring it was now possible to evaluate lean meat on live animals with great certainty.

The highest accuracy of the evaluation of meat yield is obtained in total dissection of carcass sides. First reference method of dissection used in EU countries was «Kulmbach reference method» developed by the institute of meat technology in Germany. However, this method didn't include total dissection based on tissues which was complicated, expensive and time consuming. Therefore, in countries with traditionally developed pig production a short method for determination of the carcass quality has been developed. For that purpose. EU Council (1992) has recommended a specific dissection method, introduced in 1994 (Commission Regulation (EC) No 3127/94, 1994), and described in detail by Walstra and Merkus (1996).

On slaughter line also instrumental method is applied based on optical reflection, electric conductivity of the ultra sound and video image analysis (Malovrh et al., 2002). The best known device for assessment of the quality of pig carcass sides on the slaughter line is danish apparatus »Fat-O-Meat'er" (FOM), described in Serbia by Petrović et al. (1996).

In order to carry out objective evaluation of the quality of pig carcass sides, in countries of EU, as well as in Serbia, numerous researches were carried out which relate to carcass quality and quality of pig meat (Tomović 2002; Timanović 2003; Džinić et al., 2003; Džinić et al., 2003; Fisher et al., 2003; Pulkrảbek et al., 2003; Džinić et al., 2004; Bahelka et al., 2005; Džinić 2005; Jukna i Jukna 2005; Kosovac et al., 2006; Kosovac et al., 2007; Kosovac et al., 2007; Kosovac et al., 2007; Kosovac et al., 2007; Zekić et al., 2007; Kosovac et al., 2008; Kosovac et 
al., 2008; Kosovac et al., 2008; Kosovac et al., 2009; Kosovac et al., 2009; Tomović 2009).

In our country, different methods of investigation of the quality of pig carcass sides have been applied, and therefore, in order to provide full standardization in production of pig meat, it is necessary to issue domestic rulebook, in accordance to our needs and harmonized with experiences of other countries, which would determine the quality of pig carcass sides.

For the purpose of investigation of lean meat and quality of meat deriving from pigs of different genotypes, we analyzed all relevant indicators of lean meat using different methods of investigation. Objective of this work was to compare lean meat of pig carcass sides on slaughter line, with reliable evaluation of lean meat by method of dissection. This practically means that subsequent to cutting of carcass sides into four major parts in the procedure of their dissection, the share of muscle, fat and bone tissue will be determined, as well as their share in carcass side, in order to have the best possible insight into their composition.

\section{Material and methods}

Research was carried out on pig carcass sides deriving from one farm in Vojvodina. Trial included 5 pig genotypes, of which one was pure Landrace breed (L), genotype $\mathrm{A}, \mathrm{n}=13$; two hybrid combinations (Large Yorkshire $\mathrm{x}$ Landrace) $\mathrm{x}$ Duroc (LY x L) x D, genotype B, $\mathrm{n}=15$; (Large Yorkshire $\mathrm{x}$ Landrace) $\mathrm{x}$ Pietrain (LY x L) x P, genotype $\mathrm{C}, \mathrm{n}=17$; and tow recurrent mating combinations: (Large Yorkshire $\mathrm{x}$ Landrace) $\mathrm{x}$ Large Yorkshire $(\mathrm{F} 1 \mathrm{x}$ LY, genotype $\mathrm{D}, \mathrm{n}=11)$ and (Large Yorkshire x Landrace) x Landrace (F1 x L, genotype E, $n=14)$. On total number of 70 carcasses of 5 different genotypes the carcass side quality indicators, lean meat and tissue distribution in pig carcass sides were evaluated. Carcass side lean meat was evaluated in two ways:

1. On warm carcass sides, using FOM apparatus (Petrović et al., 1997), and data obtained on thickness of fat tissue and diameter of $\mathrm{M}$. longissimus dorsi were determined on following measuring points:

$\mathrm{LF}=$ thickness of fat tissue (with skin) in millimeters, measured $8 \mathrm{~cm}$ off the medial carcass line, between 3rd and 4th lumbar vertebrae, from the caudal-cranial position

$\mathrm{RF}=$ thickness of fat tissue (with skin) in milimeters, measured $7 \mathrm{~cm}$ off the medial carcass line, between 3rd and 4th rib from caudo-cranial side, and

$\mathrm{RM}=$ diameter of $\mathrm{M}$. longisimus dorsi (MLD) in milimeters, measured at the same time and same location as RF.

Linear measures LF, RF and RM were taken manually using precision ruler.

Based on established data the lean meat percentage was calculated in carcass sides using mathematical model (Petrović et al., 1997). 
2. Method of partial dissection on cooled $\left(+4^{\circ} \mathrm{C}\right)$ left carcass sides, according to method described in detail by Walstra and Merkus (1996), on 70 carcasses following average valueswere calculated: mass of carcass muscle, mass of skin with subcutaneous tissue (KoPo), mass of intramuscular fat tissue (IMMT), as well as lean meat of carcasses.

Samples characteristic for quality of meat were taken from second back muscle (Musculus longissimus dorsi-MLD), between 13th and 14th rib. Water content was determined by reference JUS ISO 1442 method (1998), and content of free fat by reference JUS ISO 1444 method (1998). Content of total ashes was determined by method of burning JUS ISO 936 (1999). Water binding capacity (in \%) was expressed according to method by Grau and Hamm (1953), colour of meat was determined based on absorption of water extract of meat by method according to Haru (Rede and Rahelic 1969a), and total pigments according to method by Horsney (Rede and Rahelić 1969b).

Obtained data were processed statistically by method of variance analysis, and statistical significance between mean values was analyzed by Tukey test and ttest. Statistical processing of data was done using computer program Stat. Soft. STATISTIKA, version 8 .

\section{Results and discussion}

Relevant indicators of the quality of carcasses from pigs of different genotypes, evaluated using the method of partial dissection and on slaughter line are presented in table 1. It is evident from the data presented in table that the highest mass of muscle tissue in four major carcass parts with tender loin was registered in three hybrid fatteners with pietrain - group C $(15,33 \mathrm{~kg})$. Established differences were statistically significant $(* p<0,05)$ and very significant $(* * p<0,01)$.

Also, it is obvious from presented results that three hybrid fatteners F1x P (genotype C) had the lowest average thickness of fat tissue on back (LF) - 13,37 $\mathrm{mm}$, whereas the pure L breed fatteners had the highest average thickness of fat tissue on back (LF) - 19,75 mm. Recurrent mating combination with Landrace (F1x L) had the lowest average back fat thickness (RF) - 11,62 mm, whereas heads of pure L breed had the highest average back fat thickness (RF) -14,00 mm. The highest average diameters of $M$. longissimus dorsi (RM) 62,62 and 62,25 mm were established in heads of genotypes E and C (F1x L and F1 x P). Established differences between investigated traits (LF, RF and RM) and different genotypes weren't statistically significant. The greatest average area of MLD was established in heads of hybrid combination with Pietrain $54,09 \mathrm{~cm}^{2}$ and by testing of differences siignificance at the level of 5\% was established. 
Similar research was carried out by Tomović (2002), Kosovac et al. (2006), Kosovac et al. (2007), Kosovac et al. (2007), Kosovac et al. (2008), Kosovac et al. (2008), and in their research they stated higher values of the share of muscle tissue in four major carcass parts (from 15,81 to $17,73 \mathrm{~kg}$ ). Obtained values of the back fat thickness and MLD diameter (LF, RF and RM) in our researches are similar to results obtained by some authors (Tomović, 2002; Kosovac et al., 2009), and contrary to results obtained by Timanović (2003), where obtained values for thickness of fat tissue and MLD diameter (LF, RF and RM) were higher compared to results of our research $(19,10 ; 16,9$ and $69,6 \mathrm{~mm})$.

Table 1. Indicators of quality of pig carcasses obtained by application of different methods for evaluation of share of muscle tissue

\begin{tabular}{|c|c|c|c|c|c|c|}
\hline Trait & 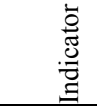 & A & B & $\mathrm{C}$ & $\mathrm{D}$ & $\mathrm{E}$ \\
\hline \multirow{2}{*}{$\begin{array}{l}\text { Mass of cooled } \\
\text { left carcass } \\
\text { sides, } \mathrm{kg}\end{array}$} & average & $39,94^{\mathrm{ab}}$ & $38,32^{\mathrm{a}}$ & $40,53^{\mathrm{ab}}$ & $39,10^{\mathrm{ab}}$ & $41,21^{\mathrm{b}}$ \\
\hline & $\mathrm{Sd}$ & 1,69 & 1,62 & 2,02 & 2,77 & 1,24 \\
\hline \multirow{2}{*}{$\begin{array}{l}\text { Yield of muscle } \\
\text { tissue in } 4 \\
\text { major parts } \\
\text { with tender } \\
\text { loin, kg }\end{array}$} & average & $12,94^{\mathrm{ab}, \mathrm{A}, \mathrm{CD}, \mathrm{EF}}$ & $12,69^{\mathrm{a}, \mathrm{AB}, \mathrm{C}, \mathrm{EF}}$ & $15,33^{\text {ab,B,D,E }}$ & $12,87^{\mathrm{ab}, \mathrm{AB}, \mathrm{CD}, \mathrm{F}}$ & $14,71^{\mathrm{b}, \mathrm{AB}, \mathrm{CD}, \mathrm{EF}}$ \\
\hline & $\mathrm{Sd}$ & 0,97 & 1,00 & 1,43 & 1,27 & 1,58 \\
\hline \multirow{2}{*}{$\begin{array}{l}\text { Yield of meat } \\
\text { in carcass sides, }\end{array}$} & average & $17,32^{\mathrm{a}, \mathrm{cd}, \mathrm{A}, \mathrm{CD}, \mathrm{EF}, \mathrm{xy}}$ & $16,67^{\mathrm{ab}, \mathrm{cd}, \mathrm{AB}, \mathrm{C}, \mathrm{EF}, \mathrm{x}}$ & $21,00^{a b, c d, B, C D, E, y}$ & $17,16^{\mathrm{ab}, \mathrm{c}, \mathrm{AB}, \mathrm{CD}, \mathrm{F}, \mathrm{xy}}$ & $20,53^{\mathrm{b}, \mathrm{d}, \mathrm{AB}, \mathrm{D}, \mathrm{EF}, \mathrm{xy}}$ \\
\hline & $\mathrm{Sd}$ & 1,31 & 1,62 & 2,57 & 1,58 & 1,72 \\
\hline \multirow{2}{*}{$\begin{array}{l}\text { Lean meat, \% } \\
\text { partial diss. }\end{array}$} & average & $43,34^{\mathrm{ab}, \mathrm{cd}, \mathrm{A}}$ & $43,34^{\mathrm{a}, \mathrm{cd}, \mathrm{AB}}$ & $51,23^{\mathrm{b}, \mathrm{c}, \mathrm{B}}$ & $44,01^{\mathrm{ab}, \mathrm{d}, \mathrm{AB}}$ & $48,82^{\mathrm{ab}, \mathrm{cd}, \mathrm{AB}}$ \\
\hline & $\mathrm{Sd}$ & 3,32 & 3,99 & 5,17 & 4,60 & 3,85 \\
\hline \multicolumn{7}{|c|}{ Back fat thickness., mm } \\
\hline \multirow{2}{*}{ LF } & average & 19,75 & 17,86 & 13,37 & 18,30 & 16,37 \\
\hline & $\mathrm{Sd}$ & 4,43 & 5,58 & 4,21 & 3,27 & 3,81 \\
\hline \multirow{2}{*}{ RF } & average & 14,00 & 13,28 & 12,62 & 12,00 & 11,62 \\
\hline & $\mathrm{Sd}$ & 3,81 & 4,38 & 4,77 & 3,97 & 4,24 \\
\hline \multirow{2}{*}{$\begin{array}{l}\text { Diameter } \\
\text { MLD, mm } \\
\text { RM }\end{array}$} & average & 59,25 & 59,57 & 62,25 & 58,60 & 62,62 \\
\hline & $\mathrm{Sd}$ & 3,99 & 9,71 & 7,57 & 5,50 & 3,92 \\
\hline \multirow{2}{*}{$\begin{array}{l}\text { Lean meat, \%: } \\
\text { FOM }\end{array}$} & average & 55,73 & 56,94 & 60,73 & 56,81 & 59,16 \\
\hline & $\mathrm{Sd}$ & 3,03 & 5,81 & 3,40 & 3,50 & 3,22 \\
\hline \multirow{2}{*}{$\begin{array}{l}\text { Area of MLD } \\
\mathrm{cm}^{2}\end{array}$} & average & $44,66^{\mathrm{a}, \mathrm{cd}}$ & $45,95^{\mathrm{ab}, \mathrm{cd}}$ & $54,09^{\mathrm{b}, \mathrm{c}}$ & $45,68^{\mathrm{ab}, \mathrm{d}}$ & $51,97^{\mathrm{ab}, \mathrm{cd}}$ \\
\hline & $\mathrm{Sd}$ & 3,19 & 5,80 & 7,76 & 5,37 & 5,23 \\
\hline \multirow{2}{*}{$\begin{array}{l}\text { Weight of } \\
\text { MLD, } \\
\text { kg }\end{array}$} & average & 2,82 & 2,93 & 3,31 & 2,91 & 3,27 \\
\hline & $\mathrm{Sd}$ & 0,38 & 0,39 & 0,31 & 0,56 & 0,39 \\
\hline \multirow{2}{*}{ Fat, kg } & average & $0,98^{\mathrm{a}}$ & $0,74^{\mathrm{ab}}$ & $0,53^{\mathrm{b}}$ & $0,78^{\mathrm{ab}}$ & $0,75^{\mathrm{ab}}$ \\
\hline & $\mathrm{Sd}$ & 0,24 & 0,36 & 0,14 & 0,26 & 0,26 \\
\hline
\end{tabular}

$\mathrm{a}-\mathrm{d}$ significance at the level of $0,05(* \mathrm{p}<0,05) ; \mathrm{A}-\mathrm{F}$ significance at the level of $0,01(* * \mathrm{p}<0,01) ; \mathrm{x}, \mathrm{y}-$ significance at the level of $0,001(* * * \mathrm{p}<0,001)$ 
Table 2. The effect of genotype on yield of main tissues in four major carcass parts determined by method of partial dissection

\begin{tabular}{|c|c|c|c|c|c|c|c|c|c|}
\hline \multirow{2}{*}{$\underset{\Xi}{\stackrel{\Xi}{\leftrightarrows}}$} & \multirow{2}{*}{ 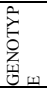 } & \multicolumn{2}{|l|}{ LEG } & \multicolumn{2}{|c|}{ SHOULDER } & \multicolumn{2}{|c|}{ BLP } & \multicolumn{2}{|c|}{ BRP } \\
\hline & & $\mathrm{kg}$ & $\%$ & $\mathrm{~kg}$ & $\%$ & $\mathrm{~kg}$ & $\%$ & $\mathrm{~kg}$ & $\%$ \\
\hline \multirow{10}{*}{ 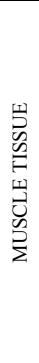 } & \multirow{2}{*}{ A } & 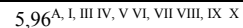 & 64,59 & $2,46^{\text {a,cd,ef,gh }}$ & $52,06^{\mathrm{ab}}$ & 2,82 & $42.24^{\mathrm{a}, \mathrm{A}}$ & 1,68 & 35,56 \\
\hline & & $\pm 0,51$ & $\pm 4,96$ & $\pm 0,11$ & $\pm 3,61$ & $\pm 0,38$ & $\pm 5,83$ & $\pm 0,22$ & $\pm 5,61$ \\
\hline & \multirow{2}{*}{ B } & $5,74^{\mathrm{AB}, \mathrm{I}}$ II, III, V, VII VIII, IX X & 67,59 & $2,38^{\mathrm{ab}, \mathrm{c}, \mathrm{e}, \mathrm{gh}}$ & $50,72^{\mathrm{a}}$ & 2,93 & $46,80^{\mathrm{ab}, \mathrm{AB}}$ & 1,62 & 39,08 \\
\hline & & $\pm 0,38$ & $\pm 2,69$ & $\pm 0,28$ & $\pm 4,89$ & $\pm 0,40$ & $\pm 7,44$ & $\pm 0,25$ & $\pm 6,40$ \\
\hline & \multirow{2}{*}{$\mathrm{C}$} & 7,30 AB, II, IV,V VI, VII, IX X & 69,67 & $2,79^{\text {ab,d,ef,gh }}$ & $57,71^{\mathrm{b}}$ & 3,31 & $54,42^{\text {ab, B }}$ & 1,91 & 44,99 \\
\hline & & $\pm 2,66$ & $\pm 4,29$ & $\pm 0,30$ & $\pm 5,01$ & $\pm 0,30$ & 5,42 & $\pm 0,34$ & $\pm 9,24$ \\
\hline & \multirow{2}{*}{$\mathrm{D}$} & $5,79^{\mathrm{AB}, \mathrm{I}} \mathrm{II}, \mathrm{III} \mathrm{IV}, \mathrm{V}$ VI, VIII,IX & 66,22 & $2,43^{\text {ab,cd,ef,g }}$ & $53,57^{\text {ab }}$ & 2,90 & $47,86^{\mathrm{ab}, \mathrm{AB}}$ & 1,74 & 41,03 \\
\hline & & $\pm 0,59$ & $\pm 6,87$ & $\pm 0,24$ & $\pm 2,99$ & $\pm 0,55$ & $\pm 5,74$ & $\pm 0,17$ & $\pm 5,75$ \\
\hline & \multirow{2}{*}{$\mathrm{E}$} & 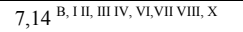 & 69,20 & $2,86^{\mathrm{b}, \mathrm{cd}, \mathrm{f}, \mathrm{h}}$ & $55,95^{\mathrm{ab}}$ & 3,21 & $51,90^{\mathrm{b}, \mathrm{AB}}$ & 1,99 & 44,36 \\
\hline & & $\pm 0,69$ & $\pm 4,73$ & $\pm 0,31$ & $\pm 3,57$ & $\pm 0,42$ & $\pm 8,69$ & $\pm 0,41$ & $\pm 8,49$ \\
\hline \multirow{10}{*}{$\begin{array}{l}0 \\
\stackrel{0}{0}\end{array}$} & \multirow{2}{*}{ A } & 1,79 & $19,63^{\mathrm{a}}$ & 1,23 & 25,95 & 1,79 & $27,11^{\mathrm{a}, \mathrm{c}, \mathrm{A}}$ & 1,72 & 37,19 \\
\hline & & $\pm 0,35$ & $\pm 3,08$ & $\pm 0,19$ & $\pm 2,88$ & $\pm 0,44$ & $\pm 5,55$ & $\pm 0,29$ & $\pm 4,94$ \\
\hline & \multirow{2}{*}{ B } & 1,39 & $16,45^{a b}$ & 1,23 & 25,93 & 1,46 & $23,15^{\text {ab,cd,AB }}$ & 1,51 & 36,04 \\
\hline & & $\pm 0,27$ & $\pm 3,05$ & $\pm 0,29$ & $\pm 4,75$ & $\pm 0,35$ & $\pm 4,86$ & $\pm 4,75$ & $\pm 0,35$ \\
\hline & \multirow{2}{*}{$\mathrm{C}$} & 1,41 & 13,34 & 1,04 & 21,22 & 1,23 & $17,75^{\mathrm{ab}, \mathrm{cd}, \mathrm{B}}$ & 1,42 & 32,38 \\
\hline & & $\pm 0,44$ & $\pm 4,35$ & $\pm 0,28$ & $\pm 4,52$ & $\pm 0,55$ & $\pm 4,60$ & $\pm 0,29$ & $\pm 5,45$ \\
\hline & \multirow{2}{*}{$\mathrm{D}$} & 1,66 & $18,70^{\mathrm{ab}}$ & 1,08 & 23,45 & 1,19 & $19,31^{\mathrm{b}, \mathrm{cd}, \mathrm{AB}}$ & 1,48 & 34,30 \\
\hline & & $\pm 0,53$ & $\pm 5,15$ & $\pm 0,23$ & $\pm 3,09$ & $\pm 0,44$ & $\pm 4,86$ & $\pm 0,31$ & $\pm 4,17$ \\
\hline & \multirow{2}{*}{$\mathrm{E}$} & 1,52 & $14,82^{\mathrm{ab}}$ & 1,15 & 22,40 & 1,23 & $19,26^{\mathrm{ab}, \mathrm{d}, \mathrm{AB}}$ & 1,71 & 37,67 \\
\hline & & $\pm 0,36$ & $\pm 3,55$ & $\pm 0,27$ & $\pm 3,95$ & $\pm 0,47$ & $\pm 5,18$ & $\pm 0,30$ & $\pm 4,31$ \\
\hline \multirow{10}{*}{$\sum_{\Sigma}^{\ominus}$} & \multirow{2}{*}{ A } & 0,69 & 7,59 & 0,50 & 10,58 & 0,57 & 8,57 & $0,84^{\mathrm{a}}$ & $18,04^{\mathrm{a}}$ \\
\hline & & $\pm 0,16$ & $\pm 1,53$ & $\pm 0,16$ & $\pm 2,80$ & $\pm 10,13$ & $\pm 1,55$ & $\pm 0,35$ & $\pm 4,37$ \\
\hline & \multirow{2}{*}{ B } & 0,89 & 10,56 & 0,54 & 11,49 & 0,62 & 9,75 & $0,70^{\mathrm{ab}}$ & $16,55^{\mathrm{ab}}$ \\
\hline & & $\pm 0,31$ & $\pm 3,69$ & $\pm 0,07$ & $\pm 1,09$ & $\pm 0,16$ & $\pm 2,84$ & $\pm 0,21$ & $\pm 4,03$ \\
\hline & \multirow{2}{*}{$\mathrm{C}$} & 0,96 & 9,10 & 0,49 & 9,94 & 0,57 & 9,30 & $0,52^{b}$ & $11,74^{b}$ \\
\hline & & $\pm 0,29$ & $\pm 3,27$ & $\pm 0,16$ & $\pm 2,24$ & $\pm 0,17$ & $\pm 2,86$ & $\pm 1,55$ & $\pm 2,75$ \\
\hline & \multirow{2}{*}{ D } & 0,70 & 7,96 & 0,45 & 9,78 & 0,61 & 10,40 & $0,73^{\mathrm{ab}}$ & $16,83^{\mathrm{ab}}$ \\
\hline & & $\pm 0,19$ & $\pm 1,85$ & $\pm 0,12$ & $\pm 2,49$ & $\pm 0,18$ & $\pm 3,09$ & $\pm 0,21$ & $\pm 3,69$ \\
\hline & $\Gamma$ & 0,83 & 8,07 & 0,55 & 10,88 & 0,56 & 8,92 & $0,60^{\mathrm{ab}}$ & $14,40^{\mathrm{ab}}$ \\
\hline & $\mathrm{L}$ & $\pm 0,20$ & $\pm 1,96$ & $\pm 0,11$ & $\pm 2,50$ & $\pm 0,16$ & $\pm 1,84$ & $\pm 0,18$ & $\pm 5,57$ \\
\hline & $A$ & 0,91 & 8,56 & 0,64 & 13,53 & 1,18 & 17,89 & 0,36 & 7,79 \\
\hline & & $\pm 0,40$ & $\pm 0,66$ & $\pm 0,22$ & $\pm 4,96$ & $\pm 0,29$ & $\pm 3,70$ & $\pm 0,09$ & $\pm 1,82$ \\
\hline & $\mathrm{D}$ & 0,84 & 9,87 & 0,84 & 9,87 & 1,13 & 17,87 & 0,35 & 8,33 \\
\hline & D & $\pm 0,07$ & $\pm 0,81$ & $\pm 0,07$ & $\pm 0,81$ & $\pm 0,16$ & $\pm 1,99$ & $\pm 0,04$ & $\pm 1,11$ \\
\hline 坟 & $\mathrm{C}$ & 0,88 & 8,32 & 0,55 & 11,32 & 1,09 & 17,65 & 0,31 & 7,11 \\
\hline ○ & & $\pm 0,12$ & $\pm 0,95$ & $\pm 0,04$ & $\pm 1,36$ & $\pm 0,08$ & $\pm 1,79$ & $\pm 0,02$ & $\pm 0,73$ \\
\hline & I & 0,85 & 9,65 & 0,61 & 13,45 & 1,16 & 19,27 & 0,31 & 7,22 \\
\hline & D & $\pm 0,06$ & $\pm 0,74$ & $\pm 0,13$ & $\pm 2,10$ & $\pm 0,14$ & $\pm 2,65$ & $\pm 0,04$ & $\pm 0,74$ \\
\hline & $F$ & 0,85 & 8,20 & 0,55 & 10,76 & 1,12 & 18,01 & 0,30 & 6,78 \\
\hline & & $\pm 0,08$ & $\pm 0,48$ & $\pm 0,02$ & $\pm 0,83$ & $\pm 0,17$ & $\pm 2,42$ & $\pm 0,02$ & $\pm 0,47$ \\
\hline
\end{tabular}

a-d significance at the level of $0,05\left({ }^{*} \mathrm{p}<0,05\right) ;$ A - F significance at the level of $0,01(* * \mathrm{p}<0,01)$;

$\mathrm{I}-\mathrm{X}$ - significance at the level of $0,001(* * * \mathrm{p}<0,001)$ 
Average values which relate to yield of tissues in four major carcass parts determined according to method of partial dissection are presented in table 2 . The highest share of muscle tissue in the leg was established in hybrid combinations with Pietrain $(69,67 \%)$, and the lowest in genotype L $(64,59 \%)$. If we observe relative share of muscle tissue in shoulder $(57,71 \%)$, BLP $(54,42 \%)$ and BRP $(44,99 \%)$ of pig carcass sides, it can be established that three breed combination with Pietrain (genotype C) was better than other genotypes.

Diffrences in mean values of the relative share of muscle tissue in shoulder were significant $\left({ }^{*} \mathrm{p}<0,05\right)$, and in BLP significant and very significant $\quad\left({ }^{*} \mathrm{p}<0,05\right.$ and $* * \mathrm{p}<0,01)$, whereas established differences in share of muscle tissue in BRP were not statistically significant. By dissection of leg, shoulder, BLP and BRP it was established that pure breed fatteners L (genotype A) had more fat tissue with skin (KoPo) than hybrid combinations with Pietrain (genotype C). Differences were significant $(* \mathrm{p}<0,05)$ for share of KoPo in leg $(19,63 \%)$, significant and very significant $(* \mathrm{p}<0,05$ and $* * \mathrm{p}<0,01)$ in $\operatorname{BLP}(27,11 \%)$. The highest average relative share of IMMT in leg and shoulder (10,56 and 11,49\%) was established in hybrid combination with Duroc (genotype B), but differences in mean values between groups were not statistically significant. By testing of relative yield of IMMT and BRP significance at the level of $5 \%$ was established between Landrace $(18,04 \%)$ and hybrid combination with Pietrain $(11,74 \%)$.

Results of the research of the share of muscle tissue in leg and shoulder are contrary to results obtained by Bak et al. (2003), Timanović (2003), Kušeca et al. (2006), Kosovac et al. (2006), Kosovac et al. (2007), Kosovac et al. (2007), Kosovac et al. (2008), Kosovac et al. (2008), Kosovac et al. (2009), since in our research lower values have been established, but similar to results obtained for share of tissues in BLP and BRP.

Table 3. The effect of genotype on variation of four major carcass parts determined by method of partial dissection

\begin{tabular}{|c|c|c|c|c|c|c|c|c|c|c|}
\hline : & & $\begin{array}{l}\text { Mass of } \\
\text { carcass }\end{array}$ & \multicolumn{2}{|c|}{ Leg } & \multicolumn{2}{|c|}{ Shoulder } & \multicolumn{2}{|c|}{ BLP } & \multicolumn{2}{|c|}{ BRP } \\
\hline & 6 & $\mathrm{~kg}$ & & $\%$ & $\mathrm{~kg}$ & $\%$ & $\mathrm{~kg}$ & $\%$ & $\mathrm{~kg}$ & $\%$ \\
\hline \multirow[b]{2}{*}{ A } & 1 & $39,94^{\text {ab }}$ & $9,23^{\mathrm{A}, \mathrm{C}, \mathrm{III}, \mathrm{III} \mathrm{I} \mathrm{V}, \mathrm{V} \mathrm{VI}, \mathrm{VII}, \mathrm{VIII}}$ & $22,87^{\mathrm{a}, \mathrm{AB}, \mathrm{CD}, \mathrm{I}, \mathrm{IIII} \mathrm{IV} \mathrm{VV}}$ & 4,74 & 11,92 & 6,59 & 16,55 & 4,62 & 11,62 \\
\hline & 3 & $\pm 1,69$ & $\pm 0,65$ & $\pm 1,11$ & $\pm 0,31$ & $\pm 0,87$ & $\pm 0,62$ & $\pm 1,27$ & $\pm 0,29$ & $\pm 0,76$ \\
\hline \multirow[b]{2}{*}{ B } & 1 & $38,32^{\mathrm{a}}$ & $8,49^{\mathrm{AB}, \mathrm{CD}, \mathrm{I}, \mathrm{III}, \mathrm{V} \mathrm{VI}, \mathrm{VII} \mathrm{VIIII}}$ & $22,16^{\mathrm{ab}, \mathrm{A}, \mathrm{CD}, \mathrm{III}, \mathrm{III}, \mathrm{V} V \mathrm{I}}$ & 4,71 & 12,28 & 6,29 & 16,44 & 4,18 & 10,91 \\
\hline & 5 & $\pm 1,62$ & $\pm 0,37$ & $\pm 0,51$ & $\pm 0,43$ & $\pm 0,99$ & $\pm 0,33$ & $\pm 0,94$ & $\pm 0,25$ & $\pm 0,67$ \\
\hline \multirow[b]{2}{*}{ C } & 1 & $40,53^{\mathrm{a}}$ & $10,48^{\mathrm{B}, \mathrm{CD}, \mathrm{II}, \mathrm{IIII} \mathrm{IV}, \mathrm{V}, \mathrm{VII} \mathrm{VIII}}$ & $25,85^{\mathrm{ab}, \mathrm{AB}, \mathrm{CD}, \mathrm{II}, \mathrm{IV}, \mathrm{V}}$ & 4,86 & 11,98 & 6,11 & 15,07 & 4,30 & 10,63 \\
\hline & 7 & $\pm 2,02$ & $\pm 0,76$ & $\pm 1,02$ & $\pm 0,53$ & $\pm 0,96$ & $\pm 0,46$ & $\pm 0,88$ & $\pm 0,35$ & $\pm 0,91$ \\
\hline \multirow[b]{2}{*}{ D } & 1 & $39,10^{\mathrm{ab}}$ & $8,76^{\mathrm{AB}, \mathrm{CD}, \mathrm{III}, \mathrm{IIIIV}, \mathrm{VI}, \mathrm{VII}}$ & $22,42^{\mathrm{ab}, \mathrm{AB}, \mathrm{C}, \mathrm{III}, \mathrm{IIII} \mathrm{IV}, \mathrm{VI}}$ & 4,55 & 11,64 & 6,08 & 15,55 & 4,28 & 10,95 \\
\hline & 1 & $\pm 2,77$ & $\pm 0,76$ & $\pm 1,34$ & $\pm 0,48$ & $\pm 0,98$ & $\pm 0,98$ & $\pm 2,35$ & $\pm 0,50$ & $\pm 1,21$ \\
\hline \multirow[b]{2}{*}{$\mathbf{E}$} & 1 & $41,21^{b}$ & $10,31^{\mathrm{AB}, \mathrm{D}, \mathrm{III}, \mathrm{IV}, \mathrm{V} \mathrm{VI}, \mathrm{VIII}}$ & $24,73^{\text {b,B,D,III, IIIIV,V VI }}$ & 5,10 & 12,25 & 6,26 & 15,00 & 4,51 & 10,81 \\
\hline & 4 & $\pm 1,24$ & $\pm 0,63$ & $\pm 1,38$ & $\pm 0,42$ & $\pm 1,11$ & $\pm 0,73$ & $\pm 1,74$ & $\pm 0,44$ & $\pm 1,05$ \\
\hline
\end{tabular}

$\mathrm{a}-\mathrm{b}$ significance at the level of $0,05\left({ }^{*} \mathrm{p}<0,05\right) ; \mathrm{A}-\mathrm{D}$ significance at the level of $0,01\left({ }^{* *} \mathrm{p}<0,01\right)$; I-

VIII significance at the level of $0,001(* * * \mathrm{p}<0,001)$ 
In table 3. the effect of genotype on variation of four major carcass side parts, determined by method of partial dissection, is presented. It is obvious from presented data that the highest absolute and relative share of leg $(10,48 \mathrm{~kg}$ and $25,85 \%$ ) is present in fatteners of hybrid combination with Pietrain (genotype C), and established differences were significant $(* p<0,05)$, very significant $(* * p<$ $0,01)$ and very highly significant $(* * * p<0,001)$. Relative yield of shoulder in carcass sides was the highest in hybrid combination with Duroc $(12,28 \%)$, genotype B, and absolute and relative share of BLP and BRP $(6,59 \mathrm{~kg}$ and $16,55 \%$; 4,62kg and 11,62\%) in Landrace. Established differences were not significant.

Summarizing the share of major parts in the carcass sides, in percentages (leg, shoulder, BLP and BRP) it can be concluded that the most favorable share of main parts is present in genotype $\mathrm{C}$, i.e. hybrid combination with Pietrain $(63,53 \%)$, followed by genotype A, i.e. fatteners of pure Landrace breed $(62,96 \%)$, genotype E, i.e. recurrent combination with Landrace (62,79\%), genotype B or hybrid combination with Duroc $(61,79 \%)$, and the lowest in genotype D, i.e. recurrent combination with Large Yorkshire $(60,56 \%)$. It is obvious from the table that there were no statistically significant differences in absolute and relative share of major carcass side parts (shoulder, BLP and BRP) between genotypes. Similar results are presented in the research by Tomović (2002), Bak et al. (2003), Kušec et al. (2006), Kapelański et al. (2006), Kosovac et al. (2007), Kosovac et al. (2007), Ukmar et al. (2008), Kosovac et al. (2008), Kosovac et al. (2008).

Table 4. Average values and significance between relative yield of meat in carcass sides determined by method of partial dissection and by FOM apparatus

\begin{tabular}{|c|c|c|c|c|}
\hline Genotype & Indicator & $\begin{array}{c}\text { Lean meat, \% } \\
\text { parc.diss. }\end{array}$ & $\begin{array}{c}\text { Lean meat, } \\
\% \\
\text { FOM }\end{array}$ & $t-$ test \\
\hline \multirow[b]{2}{*}{$\mathbf{A}$} & Average & 43,34 & 55,73 & \multirow[b]{2}{*}{$* * *$} \\
\hline & $\mathrm{Sd}$ & 3,32 & 3,03 & \\
\hline \multirow[b]{2}{*}{ B } & Average & 43,34 & 56,94 & \multirow[b]{2}{*}{$* * *$} \\
\hline & $\mathrm{Sd}$ & 3,99 & 5,81 & \\
\hline \multirow[b]{2}{*}{ C } & Average & 51,23 & 60,73 & \multirow[b]{2}{*}{$* * *$} \\
\hline & $\mathrm{Sd}$ & 5,17 & 3,40 & \\
\hline \multirow[b]{2}{*}{ D } & Average & 44,01 & 56,81 & \multirow[b]{2}{*}{$* * *$} \\
\hline & $\mathrm{Sd}$ & 4,60 & 3,50 & \\
\hline \multirow[b]{2}{*}{$\mathbf{E}$} & Average & 48,82 & 59,16 & \multirow[b]{2}{*}{$* * *$} \\
\hline & $\mathrm{Sd}$ & 3,85 & 3,22 & \\
\hline
\end{tabular}

$* * * \mathrm{p}<0,001$ 
Results of lean meat of carcass sides calculated using formula determined by EU and mathematical model of FOM apparatus are presented in table 4. Fatteners of hybrid combination with Pietrain (genotype C) had higher meat yield in carcass side, when any of the stated investigation methods were used $(51,23$ and $60,73 \%)$, compared to fatteners of other investigated genotypes. By mutual comparison of obtained results, share of muscle tissue between investigated carcass halves, statistically very highly significant differences were established $(* * * p<0,001)$. This indicates insufficient accuracy of the equation of mathematical model of FOM apparatus for calculation of lean meat percentage. Based on this we come to conclusion that equation for evaluation of the meat yield overestimates the share of meat in investigated population.

By comparison of share of meat obtained by method of partial dissection and application of method of work by FOM apparatus we come to surprisingly high difference between all investigated genotypes, and therefore additional studies are needed. Similar results were obtained by Tomović et al. (2003), Kosovac et al. (2007), where also differences were established in share of muscle tissue in carcass sides by method of partial dissection and by application of mathematical model of FOM. Timanović (2003), Ukmar et al. (2008,) by applying different methods of lean meat of pig carcass sides, have established that percentage of muscle tissue in pig carcass sides was higher when method of partial dissection was applied, which is contrary to results of our researches. In this way, once again, the insufficient accuracy of the equation of the mathematical model of FOM apparatus is confirmed, resulting in overestimating of the share of meat, and therefore additional researches are necessary.

In table 5. correlation coefficients calculated on total number of investigated animals $(n=70)$ are presented. The correlation between some indicators of the carcass quality and share of certain tissues in the carcass was investigated. It is important to point out the presence of certain correlations i.e. dependences between fat thickness (LF) and share in percentages of KoPo in leg and BLP $\left(0,68^{* *}\right.$ and $\left.0,67^{* *}\right)$, as well as between absolute share of muscle tissue in leg, shoulder and carcass $\left(0,74^{* *}\right.$ and $\left.0,82^{* *}\right)$, whereas between other stated indicators of the carcass quality and share of certain tissues no significant correlation was established. Studies by Senčić et al. (2002), Pulkrábek et al. (2003) and Pulkrábek et al. (2004) have confirmed that the best indicator of pig carcass side lean meat is fat thickness $\left(\mathrm{r}=-0,85^{* *} \mathrm{i} \mathrm{r}=-0,75^{* *}\right)$. 
Table 5. Correlation coefficients and regression equations

\begin{tabular}{|c|c|c|c|}
\hline \multicolumn{2}{|c|}{ Trait } & $\mathrm{r}$ & Regression equation \\
\hline \multicolumn{4}{|c|}{ Weight of MLD, kg } \\
\hline \multirow{3}{*}{ Muscle tissue, $\mathrm{kg}$} & Leg & $0,55^{* *}$ & $\hat{\mathrm{Y}}=3,11+1,07 \mathrm{x}$ \\
\hline & Shoulder & $0,59 * *$ & $\hat{\mathrm{Y}}=1,33+0,41 \mathrm{x}$ \\
\hline & BRP & $0,37 *$ & $\hat{Y}=1,03+0,25 x$ \\
\hline \multicolumn{4}{|l|}{ MLD area, $\mathrm{cm}^{2}$} \\
\hline \multirow{7}{*}{ Muscle tissue, $\%$} & Leg & 0,13 & $\hat{\mathrm{Y}}=62,40+0,10 \mathrm{x}$ \\
\hline & Shoulder & 0,20 & $\hat{\mathrm{Y}}=47,49+0,13 \mathrm{x}$ \\
\hline & BLP & 0,27 & $\hat{\mathrm{Y}}=33,61+0,31 \mathrm{x}$ \\
\hline & BRP & 0,20 & $\hat{\mathrm{Y}}=30,24+0,23 \mathrm{x}$ \\
\hline & Carcass & & \\
\hline & - parc.diss. & 0,31 & $\hat{\mathrm{Y}}=34,39+0,24 \mathrm{x}$ \\
\hline & - FOM & 0,22 & $\hat{\mathrm{Y}}=51,12+0,14 \mathrm{x}$ \\
\hline \multicolumn{4}{|c|}{ Back fat thickness, mm LF } \\
\hline \multirow{4}{*}{ КoPo, \% } & Leg & $0,68^{* *}$ & $\hat{Y}=6,09+0,62 x$ \\
\hline & Shoulder & $0,32 *$ & $\hat{\mathrm{Y}}=8,50+0,64 \mathrm{x}$ \\
\hline & BLP & $0,67 * *$ & $\hat{\mathrm{Y}}=7,67+0,78 \mathrm{x}$ \\
\hline & $\mathrm{BRP}$ & $0,52 * *$ & $\hat{\mathrm{Y}}=27,11+0,48 \mathrm{x}$ \\
\hline \multicolumn{4}{|c|}{ Back fat thickness, mm RF } \\
\hline \multirow{4}{*}{ КoРo, \% } & Leg & $0,55^{* *}$ & $\hat{\mathrm{Y}}=9,03+0,60 \mathrm{x}$ \\
\hline & Shoulder & $0,34 *$ & $\hat{\mathrm{Y}}=9,10+0,83 \mathrm{x}$ \\
\hline & BLP & $0,65 * *$ & $\hat{\mathrm{Y}}=9,49+0,92 \mathrm{x}$ \\
\hline & BRP & $0,61 * *$ & $\hat{\mathrm{Y}}=26,60+0,69 \mathrm{x}$ \\
\hline \multicolumn{4}{|c|}{ Muscle tissue in the leg, $\mathrm{kg}$} \\
\hline \multirow{4}{*}{ Muscle tissue, $\mathrm{kg}$} & Shoulder & $0,74 * *$ & $\hat{\mathrm{Y}}=0,92+0,26 \mathrm{x}$ \\
\hline & BLP & $0,55^{* * *}$ & $\hat{\mathrm{Y}}=1,26+0,28 \mathrm{x}$ \\
\hline & BRP & $0,54 * *$ & $\hat{\mathrm{Y}}=0,61+0,19 \mathrm{x}$ \\
\hline & Carcass & $0,82 * *$ & $\hat{\mathrm{Y}}=3,92+2,28 \mathrm{x}$ \\
\hline
\end{tabular}

By investigation of the technological and chemical composition of MLD (table 6.) no statistically significant differences $\left({ }^{*} p>0,05\right)$ in water content between investigated genotypes were established (from 73,60 to 74,01\%). 
Table 6. Mean values of investigation results obtained for certain indicators of technological quality and chemical composition of MLD of investigated pig genotypes

\begin{tabular}{|c|c|c|c|c|c|c|c|c|}
\hline \multirow[b]{2}{*}{ Genotype } & \multirow[b]{2}{*}{ No. } & \multirow[b]{2}{*}{ Indicator } & \multicolumn{3}{|c|}{ Chemical composition \% } & \multirow{2}{*}{$\begin{array}{c}\text { WBC } \\
\%\end{array}$} & \multirow[b]{2}{*}{ Colour } & \multirow{2}{*}{$\begin{array}{l}\text { Total } \\
\text { pigments } \\
\mu \mathrm{g} / 100 \mathrm{~g}\end{array}$} \\
\hline & & & Water & Fat & Ashes & & & \\
\hline \multirow{2}{*}{ A } & \multirow{2}{*}{13} & Average & 73,65 & $1,66^{\mathrm{ab}, \mathrm{cd}}$ & 1,13 & $49,93^{\mathrm{ab}, \mathrm{cd}}$ & 0,59 & $29,01^{\text {ab }}$ \\
\hline & & $\mathrm{Sd}$ & 0,52 & 0,53 & 0,05 & 3,98 & 1,02 & 3,95 \\
\hline \multirow{2}{*}{ B } & \multirow{2}{*}{15} & Average & 73,71 & $1,67^{\mathrm{ab}, \mathrm{cd}}$ & 1,12 & $54,01^{\mathrm{a}, \mathrm{c}}$ & 0,45 & $28,78^{\mathrm{a}}$ \\
\hline & & $\mathrm{Sd}$ & 0,88 & 0,76 & 0,10 & 5,41 & 0,95 & 5,31 \\
\hline \multirow{2}{*}{$\mathrm{C}$} & \multirow{2}{*}{17} & Average & 73,96 & $1.23^{\mathrm{ab}, \mathrm{d}}$ & 1,16 & $47,01^{\mathrm{ab}, \mathrm{d}}$ & 0,31 & $22,01^{b}$ \\
\hline & & $\mathrm{Sd}$ & 1,58 & 0,57 & 0,06 & 3,11 & 0,09 & 3,95 \\
\hline \multirow{2}{*}{ D } & \multirow{2}{*}{11} & Average & 73,67 & $2,21^{\mathrm{b}, \mathrm{cd}}$ & 1,13 & $52,01^{\mathrm{ab}, \mathrm{cd}}$ & 0,42 & $26,86^{\mathrm{ab}}$ \\
\hline & & $\mathrm{Sd}$ & 1,24 & 0,59 & 0,07 & 5,63 & 0,15 & 4,95 \\
\hline \multirow{2}{*}{$\mathrm{E}$} & \multirow{2}{*}{14} & Average & 74,05 & $2.19^{\mathrm{a}, \mathrm{c}}$ & 1,14 & $47,12^{\mathrm{b}, \mathrm{cd}}$ & 0,43 & $24,01^{\mathrm{ab}}$ \\
\hline & & $\mathrm{Sd}$ & 0,76 & 0,44 & 0,06 & 1,02 & 0,08 & 3,06 \\
\hline
\end{tabular}

a,b,c,d - significance at the level of $0,05(* \mathrm{p}<0,05)$

Meat of pigs of three breed combinations with Pietrain (LY x SL) x P (genotype C) had the lowest share of free lipids/fats, the least exhibited colour, as well as the lowest WBC, and higher share of ashes in comparison to results of investigated genotypes $(1,23 ; 0,31 ; 47,01$ and 1,16$)$.

In research by Timanović (2003), Džinić et al. (2003), Džinić et al. (2004), Tomović et al.(2003), Jukna and Jukna (2005) majority of properties of technological quality and chemical composition of meat were similar to our results, but in our results obtained percentage of water loss was higher.

Correlation coefficients between percentage of meat determined by method of partial dissection and some indicators of technological quality and chemical composition of meat of investigated pig genotypes are presented in table 7, and are mainly low. Only the correlation coefficient determined between meat percentage and colour content in pigs of genotype $\mathrm{E}-0,81$.

Table 7. Correlation coefficients (r) between \% of meat in carcass sides (dissection) and some indicators of technological quality and chemical composition of MLD of investigated pig genotypes

\begin{tabular}{|c|c|c|c|c|c|c|}
\hline Genotype & Water & Fat & Ashes & WBC & Colour & Total pigments \\
\hline A & $-0,13$ & $-0,26$ & $-0,44$ & $-0,60$ & $-0,57$ & 0,44 \\
\hline B & 0,49 & 0,11 & $-0,25$ & 0,24 & $-0,46$ & $-0,30$ \\
\hline C & 0,39 & $-0,26$ & 0,19 & 0,10 & $-0,23$ & $-0,39$ \\
\hline D & $-0,23$ & 0,54 & 0,29 & $-0,17$ & 0,25 & 0,35 \\
\hline E & $-0,21$ & 0,13 & 0,09 & $-0,48$ & 0.81 & $-0,59$ \\
\hline
\end{tabular}




\title{
Conclusion
}

Based on presented results of the research of quality indicators, carcass side quality and quality of meat of different pig genotypes, the following can be concluded:

- The best indicator of the lean meat of pig carcass sides is mass of muscle tissue in four major parts. This conclusion derives from the fact that fatteners (genotype C), who had the highest mass of muscle tissue in four major carcass side parts $(15,33 \mathrm{~kg})$ had also the highest share of muscle tissue in carcass sides when any of the stated methods was used (51,23 and 60,73\%), compared to fatteners of other investigated genotypes.

- The highest relative yield of muscle tissue in leg, shoulder, BLP and BRP $(69,67 \%, 57,71 \%$ and $54,42 \%$ and $44,99 \%)$ was established in carcass sides of hybrid combination with Pietrain (genotype C). Landrace fatteners (genotype A) had the highest relative share of KoPo in leg, shoulder and BLP (19,63\%, 25,95\% and $27,11 \%$ ), and in BRP the highest share of KoPo was established in recurrent combination with landrace $(37,67 \%)$.

- The highest relative yield of leg $(25,85 \%)$ was established in carcass sides of genotype $\mathrm{C}$, and the highest share of BLP and BRP in carcass sides of Landrace breed $(16,55 \%$ and $11,62 \%)$, whereas the highest share of shoulder $(12,28 \%)$ was established in three breed combination with Duroc (genotype B).

- Results of this paper show that heads of three breed combination with Pietrain are characterized by higher lean meat compared to animals of other investigated genotypes, which is related to better systematical work in regard to this trait of stated genotype.

- Technological quality and chemical composition of MLD exhibited significant $(* p<0,05)$ differences in $\mathrm{WBC}$, pigment content and share of free lipids.

Finally, we can conclude that in our country different methods of investigation of the quality of pig carcass sides are applied, and therefore, in order to provide and ensure full standardization in production of pig meat it is necessary to issue domestic rulebook on the quality of pig carcasses which would reflect domestic need and experiences of other countries.

\section{Pokazatelji kvaliteta: kvalitet polutki i mesa svinja različitih genotipova}

\author{
O. Kosovac, B. Živković, ¿̌. Radović, T. Smiljaković
}

\section{Rezime}

U radu su vršena ispitivanja mesnatosti i kvaliteta mesa svinja 5 različitih genotipova, od čega jedna čista rasa landras (L) dve hibridne kombinacije: (veliki jorkšir x landras) x durok (VJ x L) x D, genotip B; (veliki 
jorkšir x landras) x pietren (VJ x L) x P, genotip C; i dve povratne kombinacije parenja: (veliki jorkšir x landras) x veliki jorkšir (F1 x VJ, grenotip D) i (veliki jorkšir x landras) x landras (F1 x L, genotip E). Analizirani su i relevantni pokazatelji mesnatosti ocenjeni rano post mortem na liniji klanja FOM metodom i metodom parcijalne disekcije na ohlađenim levim polutkama po preporuci EU.

Analizom dobijenih rezultata ustanovljeno je da je najbolji indikator mesnatosti svinjskih polutki masa mišićnog tkiva u četiri osnovna dela. Ovakav zaključak proizilazi iz činjenice zato što su tovljenici (genotip C), imali najveću masu mišićnog tkiva u četiri osnovna dela $(15,33 \mathrm{~kg})$ i najveći udeo mišićnog tkiva u butu, plećki, LSD i TRD $(69,67 \%, 57,71 \%, 54,42 \%$ i 44,99\%) i najveći udeo mišićnog tkiva u polutkama pri korišćenju bilo koje od navedenih metoda ispitivanja $(51,23 \mathrm{i} 60,73 \%)$ u odnosu na tovljenike ostalih ispitivanih genotipova.

Ispitivan je i kvalitet mesa određivanjem tehnološkog kvaliteta i hemijskog sastava MLD-a. Tehnološki kvalitet $\mathrm{i}$ hemijski sastav mesa MLD-a ispoljio je značajne $\left({ }^{*} \mathrm{p}<0,05\right)$ razlike u SVV i sadržaju pigmenata između genotipova B i C i B i E. Prosečne vrednosti za sadržaj pepela i udeo pigmenata odgovara prosečnim vrednostima koje karakteriše mišiće normalnih svojstava.

Analizom dobijenih rezultata zaključujemo da su tovljenici genotipa E imali najveći prinos mesa u polutkama no nešto umanjenog kvaliteta, što iziskuje dalji rad na poboljšanju kvaliteta mesa.

\section{References}

BAHELKA I., DEMO P., PEŠKOVIČOVÁ D. (2005): Pig carcass classification in Slovakia-New formulas for two point method and measuring instruments. Biotechnology in Animal Husbandry 21 (5-6), p 181-185.

BAK T., DENABURSKI J., KONDRATOWICZ J., MATUSEVIČIUS P. (2003): Post-slaughter evaluation of the meat content in pig carcasses. Ham dissection. Part II. Veterinarija ir zootechnika. T.21, (43), 53-58.

COMISSION REGULATION (EC) No 3127/94 of 20 December 1994 amending regulation (EC) No 2967/85 laying down detailed rules for the application of the Community scale for grading pig carcasses. Official Journal L 330, 21/12/1994, 0043-0044.

DŽINIĆ N. (2005): Uticaj endogenih i egzogenih faktora na kvalitet mesa svinja. Doktorska disertacija. Univerzitet u Banja Luci, Banja Luka.

DŽINIĆ N., PETROVIĆ LJ., TOMOVIĆ V., MANOJLOVIĆ D. (2004): "Definisanje matematičkog modela za utvrdjivanje prinosa mesa u polutkama svinja metodom dve tačke", Simpozijum: "Veterinarstvo i stočarstvo u proizvodnji zdravstveno bezbedne hrane", Zbornik kratkih sadržaja, Herceg Novi, 28.

DŽINIĆ N., PETROVIĆ LJ., TOMOVIĆ V., MANOJLOVIĆ D., TIMANOVIĆ S., TRIŠIĆ-ILIĆ S., MRDJANOV J. (2003): Uticaj višerasnog ukrštanja i 
godišnjeg doba na kvalitet polutki i mesa svinja. Savremena poljoprivreda, 52, (34) 335-337.

DŽINIĆ N., PETROVIĆ LJ., TOMOVIĆ V., MANOJLOVIĆ D., TIMANOVIĆ S., VIDANIĆ D., KURJAKOV N. (2003): Ocena kvaliteta polutki i mesa svinja rasa veliki jorkšir i švedski landras. Biotehnologija u stočarstvu 19, (5-6), s. 500.

DŽINIĆ N., PETROVIĆ LJ., TOMOVIĆ V., MANOJLOVIĆ D., TIMANOVIĆ S., VIDANIĆ D., KURJAKOV N. (2004): Ocena kvaliteta polutki i mesa svinja rasa veliki jorkšir i švedski ladras. Biotehnologija u stočarstvu, 20, 1-2, 67-73.

FISHER A.V., GREEN D.M., WHITTEMORE C.T., WOOD J.D., SCHOFIELD C.P. (2003): Growth of carcass components and its relation with conformation in pigs of three types. Meat Science, 65, 1, 639-650.

GRAU R., und HAMM R. (1953): Eine einfache Methode zur Bestimmung der Wasserbindung im Muskel. Naturwissenschaften, 40, 29-30.

JUKNA V., JUKNA C. (2005): The comparable estimatimation of meat quality of pigs breeds and their combinations in Lithuania. Biotechnology in Animal Husbandry 21 (5-6), 175-179.

JUS ISO 1442 (1998)- Odredjivanje sadržaja vode.

JUS ISO 1444 (1998) -Odredjivanje sadržaja slobodne masti.

JUS ISO 936 (1999) - Odredjivanje sadržaja pepela.

KAPELAŃSKI W., BUCZYŃSKI J.T., BOCIAN M. (2006): Slaughter value and meat quality in the Polish native Zlotnicka Spotted pig. Animal Science Papers and Reports, 24, 1, 7-13.

KOSOVAC O., JOSIPOVIĆ S., ŽIVKOVIĆ B., RADOVIĆ Č. (2007): Kvalitet polutki i mesa svinja različitih genotipova. I medjunarodni kongres tehnologija, kvalitet i bezbednost hrane- XI simpizijum tehnologije mesa NODA, Novi sad 1315. novembar 2007. Zbornik radova, 18-23.

KOSOVAC O., JOSIPOVIĆ S., ŽIVKOVIĆ B., RADOVIĆ Č., MARINKOV G., TOMAŠEVIĆ D. (2007): Comparable presentation of carcass and meat quality of different pig genotypes using modern evaluation methods. . 2nd International Congress on animal husbandry „New perspectives and challenges of sustainable livestock farming" . Belgrad-Zemun-Serbia, October 03-05 2007. Biotechnology In Animal Husbandry, 23, book 2, (5-6), p 291-301.

KOSOVAC O., STANIŠIĆ N., ŽIVKOVIĆ B., RADOVIĆ Č., PEJČIĆ S. (2008): Kvalitet trupa i mesa svinja različitih genotipova. Biotehnologija u stočarstvu, 24, 1-2, 77-86.

KOSOVAC O., ŽIVKOVIĆ B., JOSIPOVIĆ S., RADOVIĆ Č. (2008): Contribution to the study of evaluation of the quality of pig carcasses according to method recommended by EU focusing on back fat thickness. Journal of animal science, vol. 3, 2008, (215-220). Agricultural academy, Sofia.

KOSOVAC O., ŽIVKOVIĆ B., PETROVIĆ M., RADOVIĆ Č. (2006): Prilog proučavanju ocene kvaliteta svinjskih trupova po metodi datoj u preporuci EU sa posebnim osvrtom na debljinu slanine na grebenu. Biotehnologija u stočarstvu, 22,(5-6), 89-98. 
KOSOVAC O., ŽIVKOVIĆ B., RADOVIĆ Č. (2007): Prinos mesa u trupovima svinja različitih genotipova. 42. Hrvatski I 2. Medjunarodni Simpozij agronoma, Opatija 13.-16. Veljače 2007. Zbornik radova 548-551.

KOSOVAC O., ŽIVKOVIĆ B., RADOVIĆ Č., MARINKOV G., TOMAŠEVIĆ D., DELIĆ N., PEJČIĆ S. (2007): Prilog poznavanju uticaja debljine slanine na kvalitet trupovsvinja švedski landras. Biotehnologija u stočarstvu, 23, 1-2, 59-70.

KOSOVAC O., ŽIVKOVIĆ B., RADOVIĆ Č., SMILJAKOVIĆ T. (2009): Microclimate as an animal welfare factor in the chain of ecological production of high quality and quantity of pig carcasses. $44^{\text {th }}$ Croatian and $4^{\text {th }}$ International Simposium on agriculture,(229) Opatija, $16^{\text {th }}-20^{\text {th }}$ February, Croatia.

KOSOVAC O., ŽIVKOVIĆ B., SMILJAKOVIĆ T., RADOVIĆ Č. (2008): Kvalitet polutki, prinos i raspodela pojedinih tkiva u trupovima svinja tovljenih na konvencionalan način i na dubokoj prostirci. Veterinarski glasnik 62 (3-4), 179188.

KOSOVAC O., ŽIVKOVIĆ B., SMILJAKOVIĆ T., RADOVIĆ Č. (2008): Pietrain as Terminal Breed- Is It the Right Choice? $43^{\text {rd }}$ Croation $\& 3{ }^{\text {rd }}$ Intrnational Symposium on Agriculture. Proceedings. February 18-21, 2008: Opatija, Croatia. KOSOVAC O., ŽIVKOVIĆ B., SMILJAKOVIĆ T., RADOVIĆ Č. (2009): Correlation between certain parameters of pig carcass quality in unconventional housing systems. Biotehnology in Animal Husbandry 25 (1-2), 35-44.

KUŠEC G., ĐURKIN I., PETRIČEVIĆ A., KRALIK G., MALTAR Z. (2006): Utjecaj spola na distribuciju tkiva u svinjskim polovicama. Krmiva 48, 3, 131-142.

LE ROY P.( 2002): New traits in pig breeding. V: 7th World Congress on Genetics Applied to Livestock Production, Montpellier, 19-23 avg. 2002. Castanet-Tolosan, INRA, vol. 30: 27-34.

MALOVRH Š., ČANDEK-POTOKAR M., KOVAČ M.( 2002): Metode merenja na klavini in mesnatost prašičev v EU. Slobodno kmetijstvo. Priloga: Slovenska praščereja V. 35: 259-263.

MOELLER S.J. (2001): Evolution and use of ultrasonic tecnology in the swine industry. V: International Animal Agriculture and Food Science Conference, Indianapolis, 24-28 jul. 2001. ADSA, ASAS, PSA, AMSA.

PETROVIĆ LJ., MANOJLOVIĆ D., DŽINIĆ N., LATOVSKA E., VELIMIR J., ADAMOVIĆ J. (1996): Evaluation of carcass and meat quality on the slaughterline of pigs with FOM-device. 12nd ICoMST, Proceedings, G-7, 246. lillehammer, Norway.

PETROVIĆ LJ., PAJKIĆ D., MANOJLOVIĆ D., DŽINIĆ N., TIMANOVIĆ S., JOVANOVIĆ G. (1997): Kvalitet trupova i mesa svinja dva genotipa. 46. savetovanje industrije mesa Jugoslavije, Vrnjačka Banja, poster.

PULKRÀBEK J., PAVLIK J., VALIŠ L., ČECHOVẢ M. (2003): Pig carcass classification based on the Iean meat content. Sbornik Mendlovy zemědělskẻ a lesnickẻ univerzity, Brno, 51, 109-113. 
PULKRÁBEK J., PAVLíK J., VALIŠ L. (2004): Pig carcass quality and $\mathrm{pH}_{1}$ values of meat. Czech J. Anim.Sci., 49, (1), 38-42.

REDE R., RAHELIĆ S. (1969a): Priručnik za pregled i fizičko-hemijska ispitivanja u industriji mesa. Tehnologija mesa.

REDE R., RAHELIĆ S. (1969b): Priručnik za pregled i fizičko-hemijska ispitivanja u industriji mesa. Tehnologija mesa.

SENČIĆ Đ., ŠPERANDA T., ŠPERANDA M., ANTUNOVIĆ Z. (2002): Correlation between carcass sides meatness and ultrasound measures on live pigs. X International Symposium "Animal Science Day". Kaposvar, 20-22. September, 2002. Acta Agraria Kaposvariensis, 6, 2: 265-268.

TIMANOVIĆ S. (2003): Efekat različitih modela selekcije i šema ukrštanja na prinos i kvalitet mesa svinja. Doktorska disertacija, Poljoprivredni fakultet, Novi Sad.

TOMOVIĆ, V.(2002): Uticaj selekcije i višerasnog ukrštanja svinja na kvalitet polutki i tehnološki, nutritivni i senzorni kvalitet mesa. Magistarski rad. Tehnološki fakultet, Novi Sad.

TOMOVIĆ V. (2009): Uticaj brzine hladjenja polutki, vremena otkoštavanja post mortem i postupka salamurenja na kvalitet i bezbednost kuvane šunke. Doktorska disertacija, Tehnološki fakultet, Novi Sad.

TOMOVIĆ V., PETROVIĆ LJ., DŽINIĆ N., MANOJLOVIĆ D., TIMANOVIĆ S., TRIŠIĆ-ILIĆ S., MRĐANOV J. (2003): Kvalitet polutki i prinos mesa recipročnih hibrida dobijenih ukrštanjem svinja rasa veliki jorkšir i švedski landras. Biotehnologija u stočarstvu 19, (5-6), s.503.

UKMAR R., DJURKIN I., MALTAR Z., KRALIK G., PETRIČEVIĆ A., KUŠEC G. (2008): Mesnatost i sastav klaonički obradjenih trupova svinja u Hrvatskoj. Meso: prvi hrvatski časopis o mesu, X, 6, 452-458.

WALSTRA P., and MERKUS G.S.M. (1996). Procedure for assesment of the lean meat percentage as a consequence of the new EU reference dissection method in pig carcass classification. DLO- Research institute for Animal Science and Health (ID-DLO), Zeist, The Netherlands, 1-22.

ZEKIĆ V, OKANOVIĆ Đ., ŽIVKOVIĆ B. (2007): Ekonomski aspekti proizvodnje svinjskog mesa. Savremena poljoprivreda 56, 1-2, str. 206-211. 